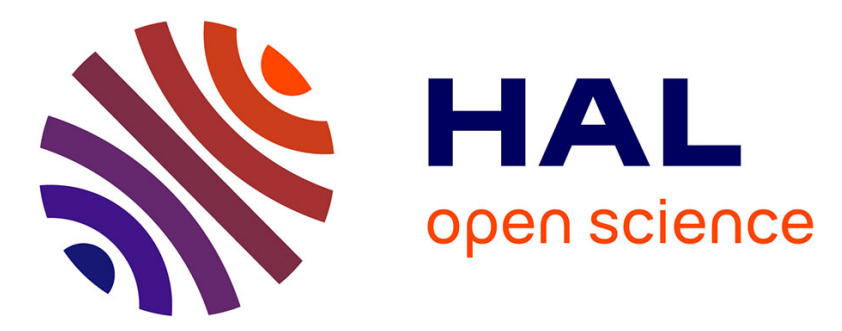

\title{
Climate variability drives livestock farmers to modify their use of collective summer mountain pastures
}

\author{
Cyrille Rigolot, Samuel Roturier, Benoit Dedieu, Stéphane Ingrand
}

\section{To cite this version:}

Cyrille Rigolot, Samuel Roturier, Benoit Dedieu, Stéphane Ingrand. Climate variability drives livestock farmers to modify their use of collective summer mountain pastures. Agronomy for Sustainable Development, 2014, 34 (4), pp.899 - 907. 10.1007/s13593-014-0224-7 . hal-01615356

\section{HAL Id: hal-01615356 https://hal.science/hal-01615356}

Submitted on 27 May 2020

HAL is a multi-disciplinary open access archive for the deposit and dissemination of scientific research documents, whether they are published or not. The documents may come from teaching and research institutions in France or abroad, or from public or private research centers.
L'archive ouverte pluridisciplinaire HAL, est destinée au dépôt et à la diffusion de documents scientifiques de niveau recherche, publiés ou non, émanant des établissements d'enseignement et de recherche français ou étrangers, des laboratoires publics ou privés. 


\title{
Climate variability drives livestock farmers to modify their use of collective summer mountain pastures
}

\author{
Cyrille Rigolot • Samuel Roturier • Benoît Dedieu • \\ Stéphane Ingrand
}

Accepted: 4 March 2014 / Published online: 27 March 2014

(C) INRA and Springer-Verlag France 2014

\begin{abstract}
It is essential for grass livestock farming to cope with climate variability and, particularly, drought. A potential solution is to use collective mountain pastures, which are colder and wetter, in the summer. However, there is little knowledge on such collective pasture management. Therefore, we surveyed three collective sheep summer mountain pastures and three small and one large cattle summer mountain pastures in 2012 in the Auvergne region, France. Farmers using and managing the pastures were interviewed. We also analysed regional statistics, an economic report and a shepherd journal. Our results show that drought has incited farmers to use collective pastures. Beginning and ending dates of the summer grazing season and animal transfers have been modified by collective decisions and individual farmer strategies. We conclude that collective summer mountain pastures is a unique source of flexibility for livestock farming.
\end{abstract}

\author{
C. Rigolot $(\bowtie) \cdot S$. Roturier $\cdot$ S. Ingrand \\ Inra, UMR1273 Métafort, F-63122 Saint-Genès Champanelle, \\ France \\ e-mail: cyrille.rigolot@clermont.inra.fr \\ C. Rigolot $\cdot$ S. Roturier $\cdot$ S. Ingrand \\ AgroParisTech, UMR1273 Métafort, F-63170 Aubière, France \\ C. Rigolot $\cdot \mathrm{S}$. Roturier $\cdot \mathrm{S}$. Ingrand \\ VetAgroSup, UMR1273 Metafort, F-63370 Lempdes, France \\ C. Rigolot $\cdot \mathrm{S}$. Roturier $\cdot \mathrm{S}$. Ingrand \\ Irstea, UMR1273 Métafort, F-63170 Aubière, France \\ S. Roturier \\ Laboratoire Ecologie, Systématique, Evolution, UMR 8079, \\ AgroParisTech, Orsay, France \\ B. Dedieu \\ Inra, Development, F-63122 Saint-Genès-Champanelle, France
}

Keywords Summer mountain pasture $\cdot$ Livestock farming system $\cdot$ Collective management $\cdot$ Flexibility $\cdot$ Climate variability $\cdot$ Farmer strategy $\cdot$ Pasture

\section{Introduction}

Climate variability and the occurrence of extreme events such as droughts are likely to increase in Europe in the next century as a result of climate change (IPCC 2007). This is a threat to livestock farm sustainability, as climate partly determines the level of fodder self-sufficiency and its sustainability in grassbased farming systems (Baumont et al. 2008). The ability of livestock farming systems to respond to such perturbations is referred to as flexibility (Astigarraga and Ingrand 2011). According to Slack (1987), flexibility can be defined in a generic sense as the "ability of a system to respond, at a reasonable cost and at an appropriate speed, to planned and unanticipated changes in external and internal environments". Flexibility has been described as a key component of the adaptive capacity of farming systems (Dedieu and Ingrand 2010; Milestadt et al. 2012). Flexibility refers either to adaptive management, largely described in management sciences (Volberda 1996), or to a general property of complex adaptive systems (Dedieu and Ingrand 2010) closely related to other concepts such as resilience (Holling 2001). In this paper, we consider flexibility in its adaptive management sense.

In mountainous areas, many livestock farming systems rely partly on summer mountain pastures, defined as permanent pastures with a specific use for grazing in summer and no possibility of bringing animals back to the farm every day (Flamant et al. 1999; Fig. 1). Summer mountain pastures can be used individually or collectively, when herds from several farms are kept by a herder (shepherd or cowherd) (Gueringer et al. 2009). In this case, one farmer generally takes responsibility for the collective management. In this paper, the word 


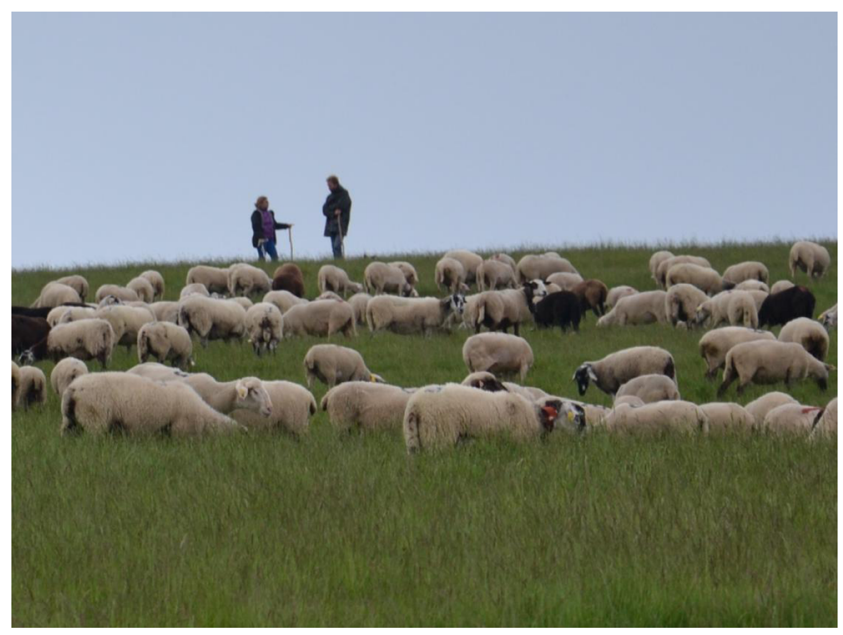

Fig. 1 Sheep herd grazing a summer mountain pasture in Auvergne. In the background, a farmer is talking with the shepherd (Source: S. Roturier)

"unit" refers to the community of farmers collectively using a summer mountain pasture. Summer mountain pastures often have a high botanical and functional diversity, which contributes to their status as remarkable environmental areas (Maurer et al. 2006; Bernués et al. 2011). This also results in a lower sensitivity to climate variability due to the temporal distribution of grass growth and complementarities between grassland communities (Duru et al. 2008). Additionally, summer mountain pastures tend to be exposed to a cooler and wetter climate than the farms due to their higher elevations.

The contribution of pastures to the flexibility of livestock farming systems has been studied recently (Andrieu et al. 2007; Martin et al. 2009). Particularly, it has been shown that pasture diversity at the farm scale provides opportunities for adaptive management (Darnhofer et al. 2010). For summer mountain pastures, however, long distances to the farm and low suitability for mechanisation limit the diversity of their possible uses for farmers (Mottet et al. 2006; Girard et al. 2008). In collective summer mountain pastures, the presence of a herder greatly modifies animal care constraints for the farmers, such as the need to tend to the animals every day. Moreover, the specific land tenure of these pastures as well as collective rules generate specific constraints of and opportunities for punctual and perennial use compared to those of private land (Eychenne 2008), especially when land is expensive (Gueringer et al. 2009). Yet, studies considering climate variability focus either on short-term changes, assuming a fixed farm structure to study farm management at an annual scale (Hervé et al. 2002; Meot et al. 2003; Martin et al. 2009), or on long-term changes, i.e. over several years (Mottet et al. 2006). We are not aware of any study that integrates interactions between both the short and long terms and climate variability. In this paper, we consider climate variability as annual fluctuations of climate key parameters (temperature, rainfall, etc.) above or below an inter-annual average value. Droughts are a major manifestation of climate variability, corresponding to periods of abnormally low rainfall that adversely modify conditions for grass growth.

Collective pastures are a typical example of a common resource pool in the scientific literature (Ostrom et al. 1999). As such, understanding their management has general implications for socioecological systems, and they have been particularly studied toward this aim (Young et al. 2006). However, as far as we know, such studies generally focus on grassland degradation and overgrazing issues in a diversity of contexts (Fernandez-Gimenez 2002; McAllister et al. 2006; Morton 2007; Li et al. 2007; Dong et al. 2011), but the link with the flexibility of individual farms has not been the main focus. We conducted a survey in 2012 in Auvergne, central France, to better understand the contribution of collective summer mountain pastures to the flexibility of livestock farming systems faced with climate variability at different time scales. In this paper, we first present the case study and methods, which are based on a diversity of both qualitative and quantitative data sources. Then, we present how collective rules and farmers' practices address exceptional droughts in the long term and climate variability in the short term. On the basis of these results, we offer profiles showing how collective summer mountain pastures can serve as a source of intra- and inter-annual flexibility in farmers' strategies to cope with climate variability.

\section{Material and methods}

\subsection{Case study}

The study was performed in Auvergne, a mountainous area in central France with an elevation range of 200-1,900 m. In this region, most livestock systems are based on the use of grass with an average stocking density of 1 livestock unit (LU)/ha. Mean annual temperature is $8.6^{\circ} \mathrm{C}$, and mean annual precipitation varies from $400 \mathrm{~mm}$ in the lowlands to more than $2,000 \mathrm{~mm}$ in the uplands above $1,000 \mathrm{~m}$ in elevation.

During the last decade, mean annual precipitation varied from 581 to $990 \mathrm{~mm}$ at an elevation of $870 \mathrm{~m}\left(45^{\circ} 43^{\prime} \mathrm{N}, 3^{\circ} 1^{\prime} \mathrm{E}\right)$, with a mean of $778 \mathrm{~mm}$. Some areas in the region have been occasionally impacted by local droughts, and the entire region was impacted by two severe droughts (2003 and 2011). In 2003, Auvergne was one of the regions most impacted by the significant water deficits in spring and summer during a heat wave that hits Europe. This resulted in a green fodder deficit of $60 \%$, with large intra-regional variability (COPA COGECA 2003). In 2011, 1 year before the beginning of our survey, the whole region was also impacted by a severe spring drought, with decreases in first-cut grass yields of 50-70 \%.

About 80,000 ha in the region are covered with summer mountain pastures grazed by 100,000 cattle and 20,000 sheep (Bordessoule 2001). This area corresponds to the uplands, 
which are associated with a higher mean annual rainfall (Fig. 2). About 10,000 ha of this area is collectively managed, particularly by sheep units. Overall, collective summer mountain pastures accommodate 11,000 sheep and 6,000 cattle. Some of these pastures are concentrated in areas with high heritage value and contribute greatly to the development of local communities (Bordessoule 2001).

\subsection{Methods}

The research material used combined qualitative and quantitative data sources from semi-structured interviews and grey literature. The interviews were performed with farmers managing and/or using collective summer mountain pastures in order to understand how their use of these pastures relates to climate variability in the long and short terms. In total, 7 managers and 15 farmers using collective pastures were interviewed once or twice between October 2011 and August 2012. The interviews were recorded and fully transcribed. Collective units were selected to encompass the diversity of locations (Fig. 2) and systems in the area, including cattle and sheep units, with the support of interviews with five local experts from extension services. We selected seven collective units with contrasting numbers of users and animals (Table 1):

- Three sheep units (S1 to S3) that are village property, with about 10 users and more than 100 ha each

- Three cattle units (C2 to $\mathrm{C} 4$ ) with less than 10 users and 100 ha each

- One cattle unit (C1) with more than 500 users belonging to the private association COPTASA (Cooperative for Transhumance and Improvement of Agricultural Structures).
Sheep units are grazed by ewes, and cattle units are grazed either by heifers or lactating cows with their calves.

Livestock farmers using collective summer mountain pastures were selected with the help of summer mountain pasture managers to describe the diversity of users. We interviewed nine sheep farmers and six cattle farmers who used one of the seven collective pastures. The areas of sheep farms ranged from 25 to 280 ha, with an average of 89 ha. Herd sizes ranged from 80 to 635 sheep, and the percentage of the herd that farmers sent to summer mountain pasture ranged from 35 to $100 \%$. The areas of cattle farms ranged from 42 to 140 ha, with an average of $82 \mathrm{ha}$, and herd sizes ranged from 40 to 120 suckling cows. The interviews with managers of collective pastures were structured with the following topics: (1) history of the summer mountain pasture, (2) technical management of the pasture related to climatic conditions and (3) relations between the organisation and the users. The interviews with users were structured as follows: (1) description of their farming system and its trajectory, (2) practices on the summer mountain pasture related to climatic conditions and (3) relations with the collective organisation. In this paper, "technical management" refers to collective rules and coordination, whereas "farmer practices" refers to the manners and motivations of farmers' actions involving the summer mountain pasture, e.g. when and why they put their animals in, what livestock category is concerned, etc. Interview transcriptions were analysed with the method of Girard et al. (2008), which identifies relevant criteria and represents farmer practices on an axis opposing two extremes. As criteria, we retained variability in the total number of animals sent to the pasture each year and in the beginning and ending dates of the grazing season (influenced by climate variability). When quantitative data were not available, e.g. when farmers did not remember
Fig. 2 The Auvergne region in France and the location of the seven collective summer mountain pastures surveyed (black and white circles) on Auvergne elevation map

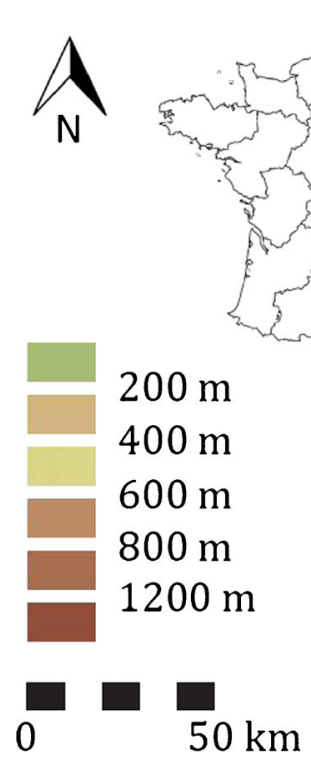

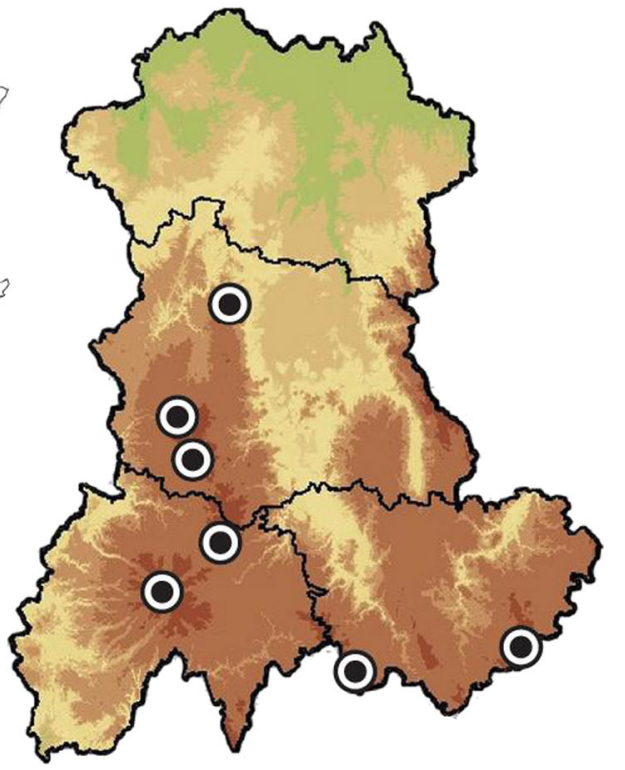


Table 1 Land tenure, area, elevation and numbers of farmers and animals in the seven collective summer mountain pastures (SMP) surveyed

\begin{tabular}{|c|c|c|c|c|c|c|c|}
\hline \multirow{2}{*}{$\begin{array}{l}\text { SMP characteristic } \\
\text { Name used in our paper }\end{array}$} & \multirow{2}{*}{$\begin{array}{l}\text { Cattle large unit } \\
\text { C1 }\end{array}$} & \multicolumn{3}{|c|}{ Cattle small unit } & \multicolumn{3}{|l|}{ Sheep unit } \\
\hline & & $\mathrm{C} 2$ & $\mathrm{C} 3$ & $\mathrm{C} 4$ & $\mathrm{~S} 1$ & S2 & S3 \\
\hline Land tenure & Private & Private & Private & Village property & Village property & Village property & Village property \\
\hline Area (ha) & 2,000 & 60 & 45 & 62 & 294 & 608 & 159 \\
\hline Mean elevation (m) & 1,350 & 1,200 & 1,300 & 1,000 & 1,400 & 1,200 & 1,300 \\
\hline Number of farmers & 500 & 7 & 6 & 4 & 11 & 12 & 10 \\
\hline Number of animals in 2012 & 3,000 & 50 & 57 & 60 & 2,000 & 2,000 & 1,200 \\
\hline
\end{tabular}

exactly, semantic analysis was used to fill in criteria based on farmers' statements (e.g. "summer pasture is my drought insurance").

In addition to the interviews, regional statistics (compiled from official authorisations to send animals to summer mountain pastures for health inspection) were used to quantify the dynamics of summer mountain pasture occupancy during the previous 12 years. Moreover, a preexisting in-depth technical-economic report performed during a 5-year period for the cattle units (Cayla et al. 1998) was used to estimate dynamics of stocking rates on the summer mountain pastures during the grazing season at an annual scale. Finally, a detailed shepherd journal was collected and analysed to quantify animal transfers between one summer mountain pasture of our survey (S3) and each individual farm. In this record, the shepherd provided information about the herd (the number of animals arriving or leaving, motivation for animal transfers, owners, veterinary treatments, etc.) and the weather from 2006 to 2011. Transversal analysis of the research material was performed for both the long and short terms. To analyse long-term trends, the interviews of summer mountain pasture managers and users were combined with regional statistics with a special focus on drought years, i.e. 2003 and 2011. For the short term, interviews were combined with the technical-economic report and the shepherd journal.

\section{Results and discussion}

3.1 Collective and individual practices related to droughts in the long term

Results indicated that droughts modify collective and individual practices in the long term. According to all summer mountain pasture managers in the interviews, droughts influenced the number of animals and farmers using summer mountain pasture as well as the number of requests from farmers to become member of the units. However, from regional statistics (results not shown), we observed no particular increase in occupancy in 2003 and 2011 due to their major droughts. The lack of direct correlation between drought years and pasture attendance can be explained by the diversity of drivers of pasture use and their interactions. In the interviews, pasture managers explained that farmer demographics, land availability, the economic context and new environmental policies are also important. This is why, according to the managers interviewed, droughts sometimes also coincide with low attendance when the economic context is not favourable, because of a lower return on investment for farmers who still have to pay fees for each animal sent. Two sheep summer mountain pasture managers (S2 and S3) explicitly considered droughts as "necessary" to maintain enough interest for upland pastures among farmers and to cover infrastructure and herder costs from year to year and, therefore, secure the summer mountain pasture in the long term.

The second main result from the interviews, related to the first, is that severe drought triggered several farmers to start using a collective summer mountain pasture. Among the 15 farmers surveyed, four began using summer mountain pastures after a drought in the 1990s and justified their decision by the drought. However, in spite of increased demand during drought years, none of the farmers interviewed reported using a collective summer mountain pasture to cope with a specific drought and leaving after just 1 year. In all collective units, a newly admitted farmer is expected to stay for several years and to send a certain number of animals each year.

The way farmers in our survey used collective pastures differed over time. At one extreme, one farmer always sent the same number of animals to a summer mountain pasture every year for 20 years, regardless of the weather or other circumstances. At the other extreme, the number of animals sent to a summer mountain pasture was strongly influenced by droughts. For example, a farmer in the S3 sheep unit modified his lambing system to send all his ewes to the summer mountain pasture after the 2003 drought. During the 2011 drought, he also sent a batch of ewe lambs to reduce the stocking rate at the farm level. Between these two extremes, the number of animals sent by other farmers in our survey changed over time, but climate variability was only a secondary factor compared to others, such as agri-environmental measures 
following the 2006 European Common Agricultural Policy reform encouraging the use of summer mountain pastures. In this case, summer pasture use can be included in a farmer's more general strategy to secure a foraging system with increasing herd size and stocking rate.

The transversal analysis of interviews with both managers and users of collective pastures illustrates how collective and individual practices are interconnected in the long term. From the collective point of view (the managers), too much flexibility in numbers and transfer dates (in and out) for individuals could threaten the integrity of the unit. Some adjustments could be accepted for farmers of the units, especially sheep units, by accepting an extra batch, but to a limited extent. In collective units, the total number of animals was limited more by herder labour constraints and summer mountain pasture infrastructure than by the vegetation and its carrying capacity. However, the study also reveals additional opportunities generated through coordinated actions among farmers in sheep and small cattle units. For example, in the C2 cattle summer mountain pasture, where heifers from four farmers grazed, a farmer who was less impacted by the 2011 drought due to his farm's local microclimate agreed to remove his heifers to leave more pasture for the others' cattle.

When an opportunity arises to put more animals on a summer mountain pasture, e.g. following the retirement of a farmer, users decide collectively either to let one of them send more animals or to accept new farmers according to specific criteria, a decision that varied among the units we surveyed. In units $\mathrm{C} 1, \mathrm{~S} 2$ and S3, priority is explicitly given to younger farmers, i.e. with small herds, rather than to older farmers aiming to increase the size of their herd. Accepting new farmers raises specific issues of trust, particularly regarding health inspections and preventive health management practices. Reciprocally, once a farmer has become a user, permanent membership is often ensured, depending on the unit's collective rules. In the large cattle unit, membership is guaranteed for farmers' entire careers and automatically offered to those who inherit their farms when they retire. In the small cattle units, local rules guarantee farmers a somewhat perennial land use. In the sheep units, rights of use belong to local farmers, whereas "foreign" users have no formal rights. According to all farmers interviewed, this has consequences on the extent to which they can rely on the collective summer mountain pasture in the long term for their foraging system.

\subsection{Collective and individual practices related to climate variability in the short term}

At the annual scale, our interviews indicate that the rules for adjusting animal transfers and beginning and ending dates of the grazing season differ among collective units. Nonetheless, all seven managers of our survey agree that ending dates are more flexible than beginning dates, due to high grass growth in spring. However, pasture managers described the diversity of rules that exist to make use of the opportunity to adjust animals leaving in autumn. In the large cattle unit, an official ending date is decided before the beginning of the grazing season (as early as March), with no consideration of future grass availability on users' farms in autumn. After this date, individual farmers are allowed to leave their animals for 2 weeks after the herdsmen have left, but the organisation is no longer responsible for animal performance. In contrast, in the small cattle and sheep units, the ending date is collectively negotiated over the course of the grazing season by the farmers and the herder. The decision takes into consideration forage availability in the collective summer mountain pasture and on individual farms, and the collective unit is responsible for animal performances until the herder leaves. Such flexibility is permitted by a variety of renewable (S3) or adjustable (S2) contracts for the herder or the ability for one farmer to privately hire the herder if the summer mountain pasture season finishes earlier (S1). In small cattle units, flexibility is ensured by the fact that one user often keeps the animals.

Between the beginning and ending dates, the intensity of animal transfers between the collective summer mountain pasture and users' farms varies among units. This is clearly illustrated in the pre-existing detailed technical-economic report used for our survey (Cayla et al. 1998; Fig. 3).

In the cattle large unit, the number of animals is marked by a large plateau: all farmers and their animals arrive in a narrow time window of a few days and leave within 1-2 weeks (Fig. 3a). In contrast, the number of animals has a shorter plateau with several decreasing steps in sheep units (Fig. 3c) and a short mid-period plateau in small cattle units (Fig. 3b). This illustrates that in sheep units, and to a lesser extent in small cattle units, exchanges between farms and the collective pasture occur throughout the entire grazing season. For sheep, this is due mainly to reproduction or selling needs during summer, as explained by interviews. However, these exchanges create opportunities to adjust stocking rates on the pastures and for individual farms to react to forage availability, for example, by delaying the transfer of ewes and their lambs to the summer mountain pasture.

Another finding indicated by the records in the shepherd's journal is that all farmers of the same collective unit did not exploit these opportunities in the same way. Transfers of sheep between individual farms and the S3 pasture (Fig. 4) clearly illustrate the contrast between farmers who continually changed the number of sheep on the pasture (farmer A) and those who kept it nearly constant throughout the season (farmer C).

The journal also illustrated opportunities for coordination between farmers during the year. Two herds from a lower elevation arrived 20 days after the others (farmer B and another farmer) to prevent overgrazing of the summer mountain pasture at the beginning of the season and to take advantage of the grass available on their own farmlands. 
a

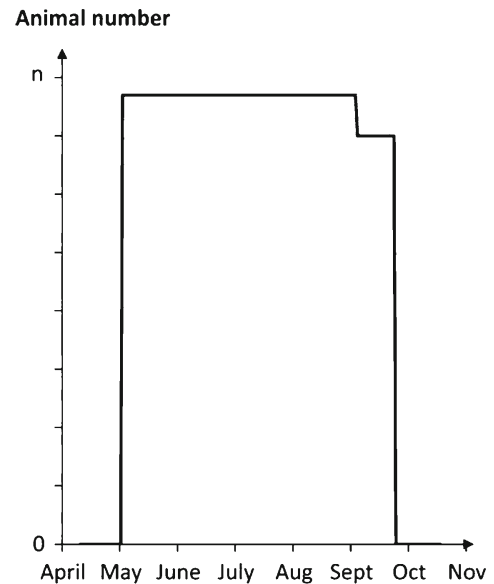

b

Animal number

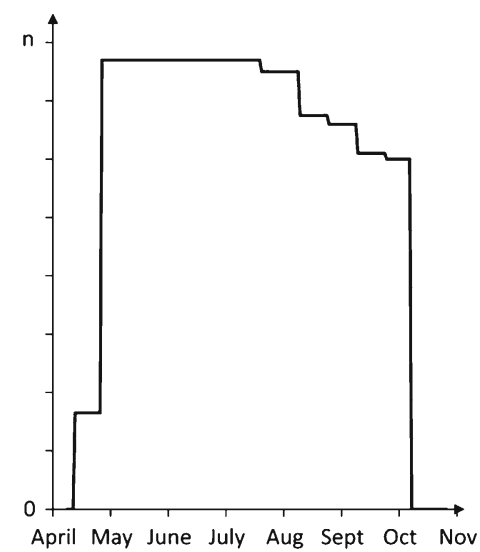

C Animal number

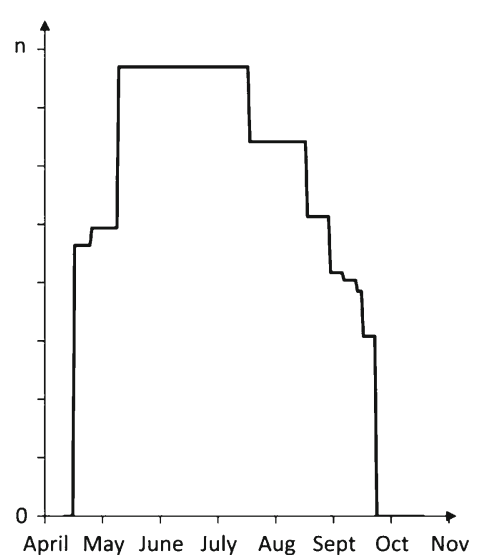

Fig. 3 Animal number dynamics in three types of collective summer mountain pastures during a typical grazing season: a cattle large unit, $\mathbf{b}$ cattle small unit and $\mathbf{c}$ sheep unit. Note the marked plateau in the cattle large unit (a) compared with the shorter plateau with several

Finally, interviews with summer mountain pasture managers and farmers also reveal trade-offs between flexibility and animal performance at the annual scale. In particular, extending summer mountain pasture grazing in autumn is risky because too little grass may be available on the summer mountain pasture at that time, and the probability of cold and wet weather is higher. In spring, it is difficult for herdsmen to manage the delayed arrival of several herds. Management of this trade-off between keeping flexibility in managing the number of animals and controlling growth or body condition of the herd in summer differs among collective units. In sheep units, the risk is shared among farmers, the herder and the collective unit. For example, both farmers and managers surveyed agree that sorting out the more fragile animals by farmers before and during summer mountain pasture grazing season increases overall animal performance, and farmers try to visit the collective summer mountain pasture several times decreasing steps in sheep units (c) and a short mid-period plateau in small cattle units (b). Adapted from Cayla et al. (1998) and interviews (a, b) and a shepherd record (c)

during the summer (unlike farmers of the large cattle unit). Hiring a new herder or acceptance of a new farmer are other sources of uncertainty, contributing (positively or negatively) to the balance between management flexibility and ensuring herd performance. According to the farmers interviewed, the ability of collective units and their users to manage these trade-offs efficiently depends on herder skills and the relevance of collective rules. The diversity revealed by our survey also suggests that regional networking could be a key to ensure a good match between farmers' objectives and the organisation of collective units.

\subsection{Profiles of summer mountain pastures' contributions to livestock farming system flexibility}

By extending the results of this study over the long and short terms, we propose four profiles of ways that collective
Fig. 4 Animal numbers dynamics per farmer during 2006 in a small sheep collective unit. Each line corresponds to a farmer. Particularly interesting are the contrast between the dynamic pattern of farmer $\mathrm{A}$ and the stability of farmer $\mathrm{C}$ contributions and the delay in the arrival of farmer B's animals in the pasture

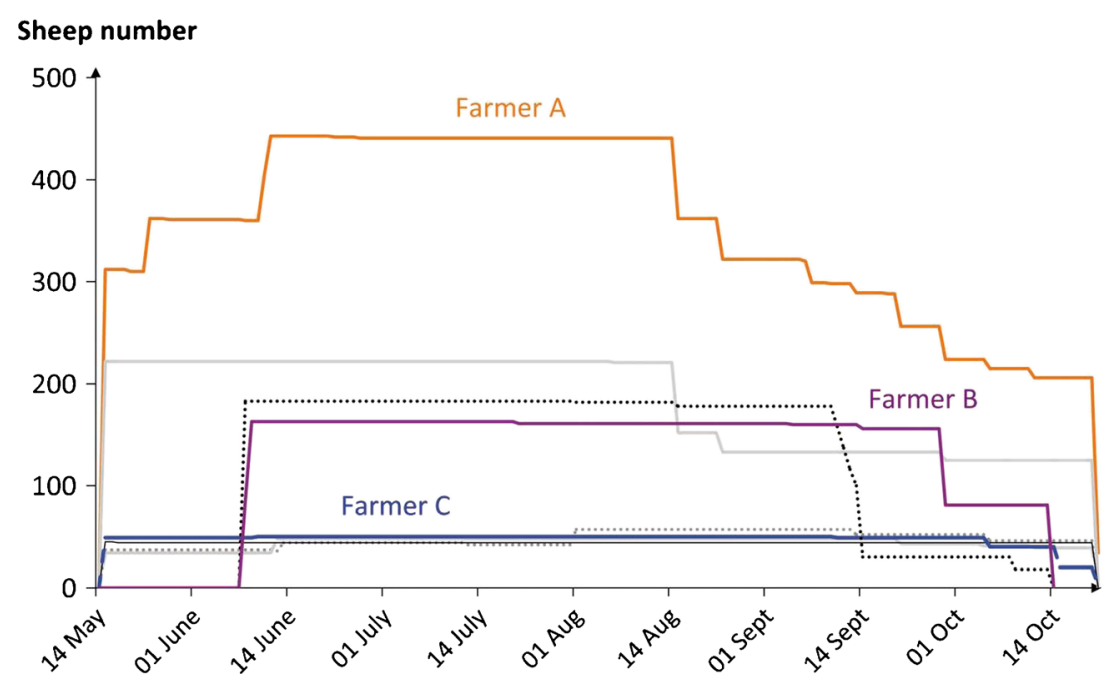


summer mountain pastures can contribute to the flexibility of livestock farming systems (Fig. 5).

The link between flexibility profiles and drought may be direct (a drought induces a change in animal numbers) or indirect (differences in animal numbers in the profiles are not directly related to a specific climatic event but can be included in a more general strategy of the farmer to secure a foraging system). The "no adjustment" profile corresponds to farmers who always send the same number of animals each year regardless of the weather. For other farmers, there are annual adjustments of animal numbers and/or intra-annual adjustments of beginning and ending dates and animal transfers. In our survey, no adjustment and "annual adjustment" profiles are relatively dominant among in the cattle large unit, whereas intra-annual adjustments are dominant in small sheep and cattle units. Some farmers, typically local managers of a small collective unit, can combine inter- and intra-annual adaptations. These profiles are consistent with different types of flexibility proposed by Volberda (1996), depending on the amplitude and speed of adaptations; no adjustment profile corresponds to steady state flexibility or to structural flexibility if it includes the moment when the farmer started to use the collective pasture (adaptation at low speed). Annual adjustment profile corresponds to strategic flexibility (major adaptation at high speed), "intra-annual" profile corresponds to operational flexibility (small adaptations at high speed), and the combination of annual and inter-annual adjustments corresponds to a flexibility mix. This is also consistent with Nozières et al. (2011), who considered the herd as a source of flexibility for livestock farming systems. Finally, in addition to direct contributions to livestock farming system flexibility, collective summer mountain pastures can also have indirect contributions, such as helping to diversify farm activities (Darnhofer et al. 2010) due to the decrease in workload in summer caused by hiring a herder. In this study, most farmers were growing crops, keeping other animal species (such as

\section{Animal number}
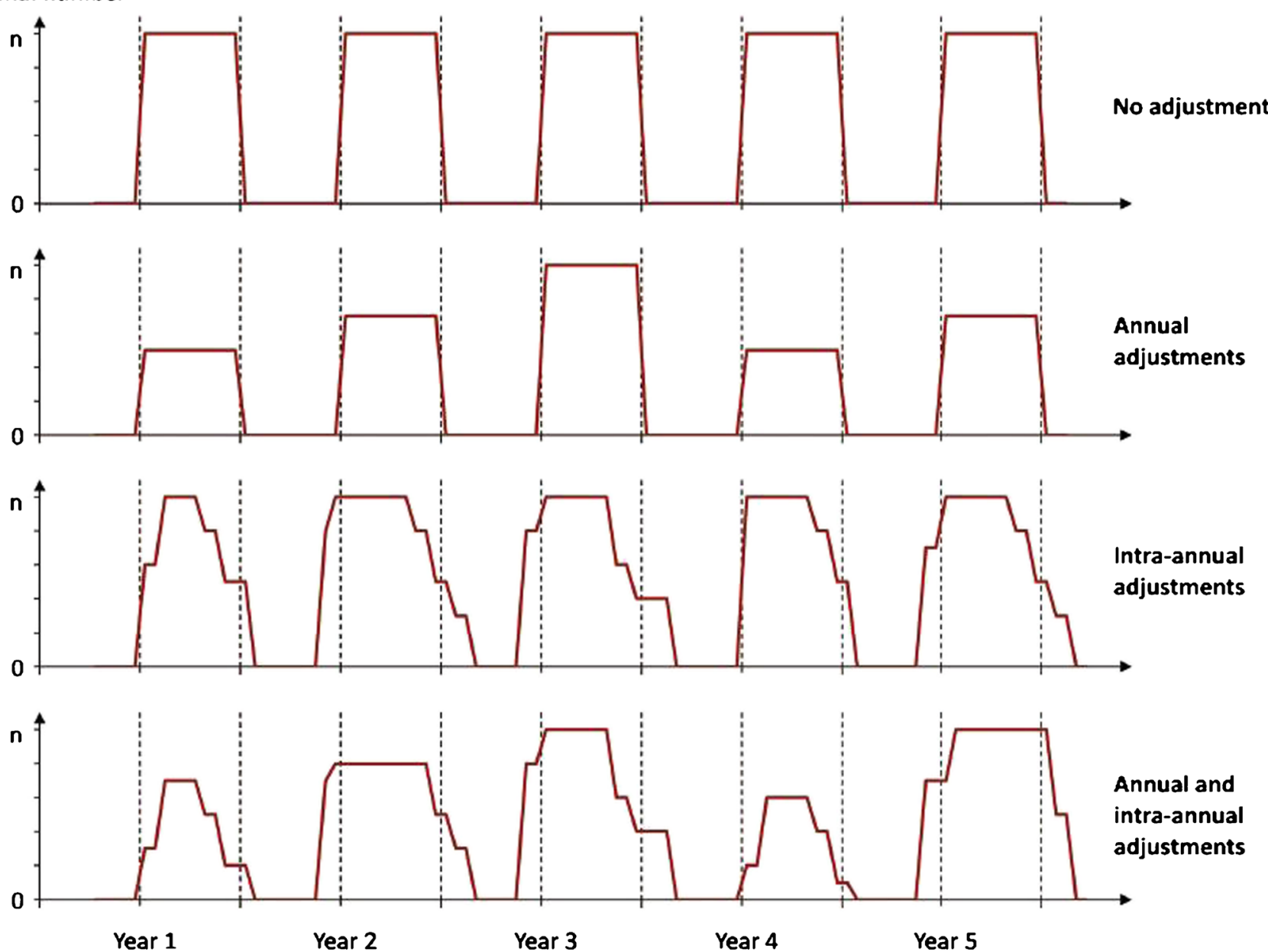

Fig. 5 Four profiles illustrating the diversity of contributions of collective summer mountain pastures to the flexibility of farmers' strategies to cope with climate variability. Red lines correspond to the number of animals sent to collective summer mountain pastures by typical

individual farmers over several years. Dotted line marks out for each year average beginning and ending dates of the collective pasture grazing season (in May and October, respectively) 
dairy cows and pigs) or performing non-farming activities during summer. A more comprehensive approach to farm flexibility could be useful to better understand interactions across scales and between climate and other sources of uncertainty, as proposed by Bathfield et al. (2013) for small coffee and honey producers facing market shocks.

\section{Conclusion}

The aim of this study was to characterise the contributions of collective summer mountain pastures to the flexibility of farmers' strategies for coping with climate variability. We found that these pastures provide different adaptation options in the long and short terms, resulting in differing types of flexibility in farmers' strategies based on their particular objectives. Flexibility is most limited by the organisation of farms and their herds as well as by collective rules and their ability to vary how many animals can be accepted each year. The diversity of mechanisms for adaptation to resource availability revealed in our study suggests that the diversity of collective pasture management and the coexistence of collective pastures with private pastures could be, in itself, a factor of flexibility at the regional scale to ensure the resilience of socioecological systems.

Further research is required to better characterise tradeoffs between flexibility and performance, for example, how adaptive management practices influence indicators of summer performance (growth and body condition). Yet, by contributing a better understanding of farmers' strategies, the results presented here could help farmers and their advisors and partners improve their use of summer mountain pastures or design new forms of collective management. To this end, the results of this study have been communicated in a technical paper to the French Association for Pastoralism and its community of professionals interested in pasture management.

Regarding the long-term scale, we did not consider the progressive increase in temperature due to climate change. In our case study, a progressive increase in temperature is expected to result in new opportunities for winter grazing and difficulties for summer grazing due to water deficits, which could strengthen interest in mountainous summer grazing. Its consequences on the use of collective mountain pastures are thus difficult to forecast, as other parameters might interact. Farm size increase opportunities in a region where livestock numbers are declining must be considered. Interactions with socioeconomic drivers of change were clearly identified in our study, but the mechanisms of these interactions remain unclear. Further research in these directions is required to better understand the development of summer mountain pastures in the context of climate change and growing uncertainty.
Acknowledgments The authors would like to thank the regional experts and farmers who took part in the interviews. This work was funded by INRA, the Auvergne Regional Council, the European Regional Development Fund and the French National Research Agency (ANR) through the projects O2LA (contract ANR-09-STRA-09) and FARMATCH (contract with Metaprogramme INRA-ACCAF).

\section{References}

Andrieu N, Poix C, Josien E, Duru M (2007) Simulation of forage management strategies considering farm-level land diversity: example of dairy farms in the Auvergne. Comput Electron Agric 55:3648. doi:10.1016/j.compag.2006.11.004

Astigarraga L, Ingrand S (2011) Production flexibility in extensive beef farming system. Ecol Soc 16:7

Bathfield B, Gasselin P, Lopez-Ridauda S, Vandame R (2013) A flexibility framework to understand the adaptation of small coffee and honey producers facing market shocks. Geogr J 179:356-368. doi: 10.1111/geoj.12004

Baumont R, Jouven M, Deux N, Farruggia A (2008) How can farms with beef cattle systems based on permanent pasture cope with extreme climatic years? Results of a study using the whole-farm simulator SEBIEN. In: Dedieu B, Zasser-Bedoya S (eds) Proceedings of the 8th European International Farming Systems Association symposium, 8-10 July 2008. INRA SAD, Clermont-Ferrand, pp 435-444

Bernués A, Ruiz R, Olaizola A, Villalba D, Casasús I (2011) Sustainability of pasture-based livestock farming systems in the European Mediterranean context: synergies and trade-offs. Livest Prod Sci 139:44-57. doi:10.1016/j.livsci.2011.03.018

Bordessoule E (2001) Les "montagnes" du Massif Central. Presses Universitaires Blaise Pascal, Clermont-Ferrand

Cayla D, Bouchy R, Lienard G (1998) Place des estives dans les systèmes allaitants Salers. Ann Zootech 47:445-451. doi:10.1051/ animres: 19980511

COPA - COGECA (2003) Assessment of the impact of the heat wave and drought of the summer 2003 on agriculture and forestry. Committee of Agricultural Organisations in the European Union - General Committee for Agricultural Cooperation in the European Union, Brussels

Darnhofer I, Bellon S, Dedieu B, Milestad R (2010) Adaptiveness to enhance the sustainability of farming systems, a review. Agron Sustain Dev 30:545-555. doi:10.1051/agro/2009053

Dedieu B, Ingrand S (2010) Incertitude et adaptation: cadres théoriques et application à l'analyse de la dynamique des systèmes d'élevage. INRA Prod Anim 23:81-90

Dong S, Wen L, Liu S, Zhang X, Lassoie JP, Yi S, Li X, Li J, Li Y (2011) Vulnerability of worldwide pastoralism to global changes and interdisciplinary strategies for sustainable pastoralism. Ecol Soc 16:10

Duru M, Cruz P, Magda D (2008) La conduite des couverts prairiaux, source de flexibilité. In: Dedieu B, Chia E, Leclerc B, Moulin CH, Tichit M (eds) L'élevage en mouvement. Flexibilité et adaptation des exploitations d'herbivores. QUAE, Versailles, pp 51-71

Eychenne C (2008) Les éleveurs et l'estive: pour une approche compréhensive des pratiques pastorales. Nat Sci Soc 16:131-138. doi:10.1051/nss:2008033

Fernandez-Gimenez ME (2002) Spatial and social boundaries and the paradox of pastoral land tenure: a case study from postsocialist Mongolia. Hum Ecol 30:49-78. doi:10.1023/A:1014562913014

Flamant JC, Béranger C, Gibon A (1999) Animal production and land use sustainability: an approach from the farm diversity at territory level. Livest Prod Sci 61:275-286. doi:10.1016/S0301-6226(99)00077-9

Girard N, Duru M, Hazard L, Magda D (2008) Categorising farming practices and designing future research regarding sustainable land- 
use management: an experience in the Central Pyrenees. Agron Sustain Dev 28:333-343. doi:10.1051/agro:2007046

Gueringer A, Rapey H, Houdart M, Bigot G, Josien E, Landré F (2009) Adaptability through spatial management. A case study of livestock farms in the Massif Central, France. Outlook Agric 38:111-118

Hervé D, Genin D, Migueis J (2002) A modelling approach for analysis of agro-pastoral activity at the one-farm level. Agric Syst 71:187206. doi:10.1016/S0308-521X(01)00044-0

Holling CS (2001) Understanding the complexity of economic, ecological, and social systems. Ecosystems 4:390-405. doi:10.1007/ s10021-001-0101-5

IPCC (2007) Climate change: the physical science basis. Contribution of working group I to the fourth assessment report of the Intergovernmental Panel on Climate Change. Cambridge University Press, Cambridge

Li WL, Ali SH, Zhang Q (2007) Property rights and grassland degradation: a study of the Xilingol Pasture, Inner Mongolia, China. J Environ Manag 85:461-470. doi:10.1016/j.jenvman. 2006.10.010

Martin G, Hossard L, Theau JP, Therond O, Josien E, Cruz P, Rellier JP, Martin-Clouaire R, Duru M (2009) Characterizing potential flexibility in grassland use. Application to the French Aubrac area. Agron Sustain Dev 29:381-389. doi:10.1051/agro:2008063

Maurer K, Weyand A, Fischer M, Stöcklin J (2006) Old cultural traditions, in addition to land use and topography, are shaping plant diversity of grasslands in the Alps. Biol Conserv 130:438-446. doi:10.1016/j.biocon.2006.01.005

McAllister RRJ, Abel N, Stokes CJ, Gordon LJ (2006) Australian pastoralists in time and space: the evolution of a complex adaptive system. Ecol Soc 11:41
Meot A, Hubert B, Lasseur J (2003) Organisation of the pastoral territory and grazing management: joint modelling of grazing management practices and plant cover dynamics. Agric Syst 76:115-139. doi:10. 1016/S0308-521X(02)00105-1

Milestadt R, Dedieu B, Darnhofer I, Bellon S (2012) Farms and famers facing change: the adaptive approach. In: Darnhofer I, Gibbon D, Dedieu B (eds) Farming systems research into the 21st century: the new dynamic. Springer, Dordrecht, pp 365-385

Morton JF (2007) The impact of climate change on smallholder and subsistence agriculture. Proc Natl Acad Sci USA 104:19680 19685. doi:10.1073/pnas.0701855104

Mottet A, Ladet S, Coque N, Gibon A (2006) Agricultural land-use change and its drivers in mountain landscapes: a case study in the Pyrenees. Agric Ecosyst Environ 114:296-310. doi:10.1016/j.agee. 2005.11.017

Nozières MO, Moulin CH, Dedieu B (2011) The herd, a source of flexibility for livestock farming systems faced with uncertainties? Animal 5:1442-1457. doi:10.1017/S1751731111000486

Ostrom E, Burger J, Field CB, Norgaard RB, Policansky D (1999) Revisiting the commons: local lessons, global challenges. Science 284:278-282. doi:10.1126/science.284.5412.278

Slack NDC (1987) Manufacturing systems flexibility: ten empirical observations. Management Research 87/9. Templeton College, the Oxford Centre for Management Studies, Oxford

Volberda H (1996) Towards the flexible form: how to remain vital in hypercompetitive environments. Organ Sci 7:359-374. doi:10. 1287/orsc.7.4.359

Young OR, Berkhout F, Gallopin GC, Janssen MA, Ostrom E, van der Leeuw S (2006) The globalization of socio-ecological systems: an agenda for scientific research. Glob Environ Chang 16:304-316. doi:10.1016/j.gloenvcha.2006.03.004 